\title{
Determinants of fiscal distress in Italian municipalities
}

\author{
Wildmer Daniel Gregori ${ }^{1}$ • Luigi Marattin ${ }^{2}$
}

Received: 13 January 2016/ Accepted: 28 November 2017 / Published online: 22 December 2017 (C) The Author(s) 2017. This article is an open access publication

\begin{abstract}
How important is to place limits on specific categories of local public spending in order to prevent municipalities' defaults? In this paper we consider Italian municipalities from 2000 to 2012 . We use a logit model to investigate which of the main budget indicators (debt repayments, current budget equilibrium, amount of residuals and personnel costs) is relatively more important in affecting the default probability. Our results suggest that a $10 \%$ rise in the share of loan repayment over total spending leads to an increase in default probability by $2.6 \%$ on average. These findings are robust to alternative model specifications and the inclusion of fixed effects, time dummies and macroeconomic control variables. Our analysis thus shows that Italian municipalities seem to be on the default path when they are incapable to fully internal-
\end{abstract}

The authors would like to thank participants in the EUROFRAME conference "Balance sheets misalignments: effects and policy implications for the EU economies" (June 2016). We are grateful to Maria Elena Bontempi, Elena Giarda, Roberto Golinelli, Gloria Moroni, Chiara Toscano and two anonymous referees for useful comments and suggestions. Any errors remain our responsibility. The views expressed in this paper are those of the authors and do not necessarily reflect official views of the European Commission. As for precious help in data collection, we are very grateful to Giancarlo Verde, Director of the Local Finance Office, at the Ministry of Interior.

Wildmer Daniel Gregori: Part of the work has been done while working at Prometeia Associazione, Via Marconi 43, 40122 Bologna, Italy.

Wildmer Daniel Gregori

wildmer.gregori@ec.europa.eu

Luigi Marattin

luigi.marattin@unibo.it

1 European Commission, Joint Research Center (JRC)-Ispra, Via Fermi 2749, 21027 Ispra, Varese, Italy

2 Economic Department, University of Bologna, Strada Maggiore 45, 40125 Bologna, Italy 
ize the effects of issuing new debt today on the current equilibrium of tomorrow. To place limits on specific types of public spending seems to be relatively less important.

Keywords Local government · Default - Local public debt · Fiscal distress · Panel regressions

\section{JEL Classification $\mathrm{H} 72 \cdot \mathrm{H} 74$}

\section{Introduction}

Fiscal coordination rules between government layers are crucial in order to guarantee sound public finances and fiscal stability of national economies. Since 1999, the Italian government has been imposing a set of constraints - the main one being the Internal Stability Pact-in order to preserve financial and fiscal discipline at the local level. These limits include upper thresholds to subcategories of either current spending (such as personnel costs and advertising) or budget balances (such as ex-post equilibrium between current revenue and current spending). The main question that we attempt to answer is whether there is any particular budget category more effective than another in signaling future fiscal distress. Particularly, the focus is on two local public spending items - personnel expenditure and loan repayments - which have been emphasized by the Italian governments policy actions, because charged of injecting too much rigidity into current spending. The former has been tightened for 2016 (turnover has been diminished to $25 \%$, and other constraints are in place ${ }^{1}$ ), and the latter has been relaxed in 2015. (Limit on interest payments has been raised from 8 to $10 \%$ of total current spending.) Possibly, an inquiry into the main determinants of default probability can provide support to policy makers in their attempt to design rules able to effectively address the ultimate causes of local defaults. In this respect, Italy represents an interesting case study: On the one hand, it is characterized by a huge variety of local governments, and on the other hand, there are detailed data available for each municipal budget. Moreover, recent policy debate stressed the need to reconsider the need of limits on specific spending categories, rather than a more stringent attention of the aggregate fiscal constraint.

A further and more general motivation of this study relies on the fact that fiscal distress of local governments and municipalities played an important role in the deterioration of public finance that occurred following the 2008 Financial Crisis. The 2013 default of Detroit - the largest city in US history to file for bankruptcy-is probably the most famous case, but by no means the only one: Famous episodes of fiscal distress in US municipalities or local governments over the years include New York, Cleveland, Miami, Pittsburgh, Philadelphia, Orange County. Budget default of subnational authorities can also be observed in Europe: The most visible episode has been Catalonia in 2012, but there have been some other significant cases in Portugal and Italy (Dexia 2006). Local government defaults can be either the cause or consequence

\footnotetext{
1 Each year personnel costs must diminish in nominal terms with respect to the last three years' average (as described in the Law 296/2006, art. 1).
} 
of national public finance tensions. Particularly in the former case, it is important to understand their determinants in order to prevent negative spillovers from lower to higher levels of governments, which are lately called in to bail out the local government. Nicolini et al. (2002) discuss several vertical bailout episodes that occurred in Argentina in the 1990s, while Von Hagen et al. (2000) focus on four subnational bailouts in the OECD area. On the other hand, sound theoretical modeling of externalities arising from local fiscal indiscipline is provided by Wildasin (1997), which explicitly links the needs of central government bailout intervention to the presence of optimal specification of fiscal decentralization and policy rules. Therefore, it seems that investigating the actual determinants of local defaults is also crucial for the policy design of fiscal constraints that national authorities usually impose on local governments. It is worth noticing, however, that national legislations on local defaults vary considerably across countries; in this paper, we focus on the Italian regulation, whose features are not necessarily similar to other experiences. Therefore, our results and policy implications do not necessarily apply to similar other local default episodes.

While there is significant literature on sovereign debt crisis and default (see, among others, Schaltegger and Weder 2015; Jorra 2012; Manasse and Roubini 2009), less attention on the same topic has been paid at the local level. There are studies on how local fiscal performances are affected by specific budget choices (see, for example, Epple and Spatt 1986; Capeci 1994; Buettner and Wildasin 2006; Skidmore and Scorsone 2011) or by the degree of decentralization (Von Hagen and Eichengreen 1996; Hausmann 1998; Richard and Musgrave 1989). There are also many analysis on local public spending efficiency (Worthington and Dollery 2000; Grossman et al. 1999; Afonso and Fernandes 2006) and local taxation (Skidmore 1999). However, to the best of our knowledge, there are no specific studies on what budget variable is a leading indicator of local fiscal distress, at least for European countries. The aim of this paper is to provide a contribution to the empirical literature on local public finance, by empirically investigating the determinants of Italian local municipalities' defaults using a panel annual dataset from 2000 to 2012. This work applies binary regression models in the attempt to identify the most important variables leading to major fiscal distress episodes. Results show that the most significant budget component increasing the probability of future default is the share of annual loan repayment over total spending. In all specifications, this debt indicator is significant in affecting the default probability: Ceteris paribus, a 10 percentage points rise in the principal index at the sample means increases the default probability by $2.6 \%$. This result is in line with the recent literature that identifies fiscal limits as debt levels beyond which the burden of interest payments greatly compresses the current spending maneuverability. There is no evidence that an increase in fiscal revenue diminishes the probability of local municipalities' fiscal distress, while the ratio between current spending over total spending seems to play a role in different econometric specifications: A 10 percentage points rise at the sample means increases the default probability by $3.7 \%$ at a significance level of $10 \%$. Other components that are often pointed out as dangerous indicators are not significant, such personnel costs, which nevertheless continue to be a policy target in the relationship between central government and municipalities. As the focus is merely on economic explanatory variables, this study is not related to the vast amount of political economy research on local public finance. 
Table 1 Budget indexes, period 2000-2012, summary statistics. Source: Aida PA, Bureau Van Dijk and authors' calculations

\begin{tabular}{lrrrr}
\hline & Mean & SD & Min. & Max. \\
\hline Principal index & 0.10 & 0.13 & 0.00 & 0.58 \\
Principal-current spending index & 0.23 & 0.36 & 0.00 & 2.13 \\
Principal-capital spending index & 3.72 & 22.34 & 0.00 & 341.07 \\
Current revenues index & 0.61 & 0.26 & 0.06 & 1.17 \\
Current spending index & 0.51 & 0.20 & 0.05 & 0.88 \\
Autonomy index & 0.39 & 0.21 & 0.02 & 1.00 \\
Residual index & 1.52 & 1.74 & 0.13 & 21.88 \\
Personnel index & 0.22 & 0.06 & 0.06 & 0.44 \\
Number of observations & 416 & 416 & 416 & 416 \\
Municipalities & 32 & 32 & 32 & 32 \\
Years & 13 & 13 & 13 & 13 \\
\hline
\end{tabular}

The remainder of this paper is organized as follows. Section 2 presents the dataset and the specification of the empirical model. Section 3 shows the results and robustness checks, while Sect. 4 offers some concluding remarks.

\section{Empirical analysis}

In this section is carry out the empirical analysis. First the data sources, descriptive statistics and binary dependent variable are illustrated (Sect. 2.1); then, it is presented the model specification (Sect. 2.2).

\subsection{Data and the default indicator}

The analysis merges different sources of information. The first one relies on an Italian database for public administration from the Ministry of the Interior, ${ }^{2}$ which includes municipality budget data, and different indicators are implemented, ${ }^{3}$ as detailed in Table 1, in order to take into account different features of local budgets, specifically: (i) principal index (i.e., loan repayment over total spending); (ib) principal-current index (i.e., loan repayment over current spending); (ic) principal-capital index (i.e., loan repayment over capital spending); (ii) current revenues index (i.e., the ratio between current revenue and total spending); (iii) current spending index (i.e., the ratio between current spending and total spending); (iv) autonomy index (i.e., tax revenue over current spending); (v) residual index (i.e., positive residuals over total revenues); (vi) personnel index (i.e., the ratio between personnel spending and current spending). In order to control for time-varying effects, the dataset also includes a set of regional

\footnotetext{
2 For further details, see http://finanzalocale.interno.it/.

3 These indicators are the one used by the Ministry of the Interior to analyze local public budgets.
} 
macroeconomic variables obtained from the National Institute of Statistics (Istat): unemployment rate, per-capita GDP and inflation rate.

At first glance, one might believe that there is an endogeneity issue between the default risk and public debt service, considering that a rising burden of public debt service could increase sovereign default risk, and vice versa rising credit default risks may increase public debt service costs. It is important to specify that it is not the case here. In fact, Italian local public finance accounting principles are such that the total debt service (i.e., principal plus interest) is split into two separate budget aggregates: (i) The principal constitutes a separate budget component and follows a fixed amortizing plan. The endogeneity issue is ruled out, as the amortizing plan is pre-determined and thus, by definition, not influenced by variation in credit default risk; (ii) the interest is included within the overall current spending, and it accounts for a small part of current spending (for instance, in 2012 it was the $3.5 \%{ }^{4}$ ). Moreover, debt of Italian municipalities is mainly taken out with Cassa Depositi e Prestiti, which applies a debt service costs defined ex-ante for all local governments (in accordance with D.L. 30-09-2003, n. 269, art. 5); therefore, credit conditions are not affected by real or perceived modifications of the credit status. Thus, rising credit default risks cannot increase public debt service costs.

The dependent variable is a binary variable $D$, a local default indicator, calculated using data from data from the Ministry of the Interior. It assumes the following values:

$$
D_{i, t}= \begin{cases}1, & \text { when a Municipality } i \text { has financial distress in year } t \\ 0, & \text { otherwise }\end{cases}
$$

The literature does not employ a unique definition of local fiscal distress, which is often country-specific: A local government is considered to default whenever it enters the conditions disciplined by national laws, due to its inability to fulfill its existing financial obligations (Lobo et al. 2011). Following the Italian Court of Auditors, in this work it is established that a municipality is in financial distress when its council votes a default resolution, an event which is specifically disciplined by Italian Law. Legislation on local defaults was introduced for the first time in $1989^{5}$ but was only permanently systematized 11 years later with the Consolidated Text of Local Governments (Decree Law 267/2000), where default is defined as a contingency in which municipalities have definite and liquid liabilities that they cannot cope with. The procedure is the following: First, the City Council votes the default resolution, which includes the report by the Audit Committee. Within five days these documents are officially transmitted to the Ministry of the Interior and to the local section of Accounting Judiciary and then officially published into the Italian Official Journal (which includes new law and administrative acts). The Ministry of Interior appoints a special committee in charge of managing the "bad loans", namely the recognition (and subsequent liquidation) of all the available credits to cope with the outstanding liabilities. At the same time the current administration is left in charge of managing the "good loans": the new balance sheet—relieved by the assets and liabilities of the "bad loans" — which is subject to

\footnotetext{
${ }^{4}$ Source: Italian Minister of Interior. The percentage is extremely stable even on a longer time span.

5 Decree Law n. 66, converted into Law n.144/1989.
} 
Table 2 Municipal defaults, by year and geographical area. Source: Ministry of Internal Affairs and authors' calculations

The Italian regions are classified as follows: (North) Piedmont, Aosta Valley, Lombardy, Trentino-South Tyrol, Veneto, Friuli-Venezia Giulia, Liguria, Emilia-Romagna; (Center) Tuscany, Marche, Lazio; (South) Abruzzo, Campania, Apulia, Calabria, Sicily, Sardinia

\begin{tabular}{llllc}
\hline & North & Center & South & Total \\
\hline 2000 & 0 & 2 & 1 & 3 \\
2001 & 0 & 0 & 0 & 0 \\
2002 & 0 & 1 & 2 & 3 \\
2003 & 0 & 0 & 1 & 1 \\
2004 & 0 & 1 & 0 & 1 \\
2005 & 0 & 0 & 2 & 2 \\
2006 & 0 & 1 & 2 & 3 \\
2007 & 0 & 0 & 0 & 0 \\
2008 & 0 & 1 & 3 & 4 \\
2009 & 0 & 1 & 0 & 1 \\
2010 & 0 & 1 & 4 & 5 \\
2011 & 2 & 0 & 4 & 6 \\
2012 & 0 & 0 & 3 & 3 \\
Total & 2 & 8 & 22 & 32 \\
\hline
\end{tabular}

severe regulations in terms of personnel costs and local taxes. Should the liquidation of available assets be insufficient to repay debts, creditors are rationed and thus we have the classical circumstances known as partial default. ${ }^{6}$

The analysis focuses on municipalities that have experienced the default event and the final database riles on 32 cases of local default. As shown in Table 2, the defaults are quite well distributed in the period analyzed and they mainly occur in municipalities in the south (22 events). ${ }^{7}$ In addition, the number of defaults increased during the Great Recession: On average, in the period 2010-2012 there has been 3.7 local defaults per year, while between 2000 and 2009 just 1.1 .

One might also wonder about the role played by revenue heterogeneity in the default probability. In principle, a municipality might have a higher probability of incurring into fiscal distress if it, ceteris paribus, receives less transfer from central government and/or has lower ability to raise own revenue. Or, put differently, if transfers fail to at least partially equalize the structural heterogeneity in local tax bases. Figure 1 shows the relative sizes of central government transfers to municipalities, local fiscal capacity ${ }^{8}$ and population. We regrouped municipalities into three aggregates ("North," "Center" and "South") in order to be consistent with later analysis. Particularly, the blue line indicates the share of people living in those municipalities. The red and green

\footnotetext{
6 Should the value of liquidable assets be below $40 \%$ of outstanding liabilities, the municipalities can benefit from a central government grant in order to bring the coverage up to between 40 and $60 \%$ of debt.

7 There are not cases of serial default, because there are 32 cases of default and 32 municipalities. In addition, for each year every default occurs among municipalities that do not share any border, excluding the idea that municipal defaults are correlated.

${ }^{8}$ Literature has used a variety of methods to compute fiscal capacity. Here we use the method employed by the Italian government, in line with the best practice. Fiscal capacity is measured with the representative tax system method for local tax instruments on real estates and income (Yilmaz et al. 2002) and with the regression-based fiscal capacity approach for other revenue sources (Akin 1973, 1974; Martinez-Vazquez 1997a, b; Di Liddo et al. 2016).
} 


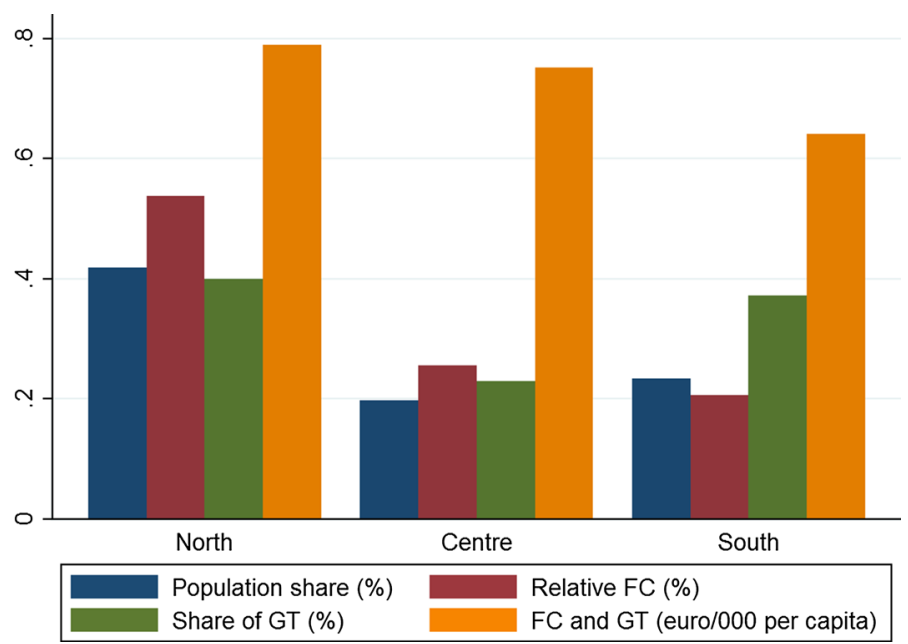

Fig. 1 Local fiscal capacity (FC) and central government transfers (GT) to municipalities by macroarea (year 2012). Population, FC and GT shares are calculated dividing the total amount in euro (FC and GT) or unit (population) of a macroarea by the total of the three macroareas. "FC and GT (euro/000 per capita)" is the sum of FC and GT, in euro, divided by the population and by 1000, for each macroarea. Source: Ministry of Internal Affairs and authors' calculations

columns indicate, respectively, the share of central government transfers and fiscal capacity, while the orange column indicates the per-capita sum of the two. Moreover, recent evidence (Di Liddo et al. 2016) on a longer time span (2000-2012) confirms the equalizer role played by central government transfers.

Based on the dataset detailed above, next subsection shows the model specification.

\subsection{Model specification}

The goal is to investigate the probability of a local default, and for this purpose, it is required a model able to deal with a binary dependent variable, where the interest lies primarily in the response probability of the covariates included in the specification. ${ }^{9}$ It is therefore implemented a logit model ${ }^{10}$ specified as follows:

$$
D_{i, t}=\alpha+\boldsymbol{\beta} \boldsymbol{B}_{i, t-1}+\boldsymbol{\gamma} \boldsymbol{C}_{\boldsymbol{r}, t}+\tau T_{t}+\epsilon_{i, t}
$$

where $D_{i, t}$ is the default indicator for municipality $i$ at time $t ; \alpha$ is a constant; $B$ is a vector of the five budget indicators; and $C$ is a vector of macroeconomic variables at the regional level $r$ to control for time-varying effects, as specified in the previous

\footnotetext{
9 For a detailed explanation of binary models, see Wooldridge (2010), while a qualitative response model survey is proposed by Amemiya (1981).

10 In the default probability literature, both logit and probit models have been used to serve this purpose, as shown by Van Rijckeghem and Weder (2009). Following King and Zeng (2001), who study rare events using the logistic regression, and in order to include fixed effects as robustness checks, in this study it is implemented the logistic specification.
} 
Table 3 Probability of default, marginal effects

\begin{tabular}{|c|c|c|c|c|c|c|c|}
\hline & Default & Default & Default & Default & Default & Default & Default \\
\hline & (1) & (2) & (3) & (4) & (5) & (6) & (7) \\
\hline Principal index $t-1$ & $\begin{array}{l}0.25^{* * * *} \\
(0.08)\end{array}$ & $\begin{array}{l}0.25 * * * \\
(0.08)\end{array}$ & $\begin{array}{l}0.26^{* * * *} \\
(0.08)\end{array}$ & $\begin{array}{l}0.26^{* * * *} \\
(0.08)\end{array}$ & $\begin{array}{l}0.25^{* * *} \\
(0.08)\end{array}$ & $\begin{array}{l}0.26^{* * *} \\
(0.08)\end{array}$ & $\begin{array}{l}0.26^{* * * *} \\
(0.08)\end{array}$ \\
\hline Current revenues index ${ }_{t-1}$ & & $\begin{array}{l}0.02 \\
(0.06)\end{array}$ & $\begin{array}{l}-0.19 \\
(0.17)\end{array}$ & $\begin{array}{l}-0.18 \\
(0.17)\end{array}$ & $\begin{array}{l}-0.18 \\
(0.17)\end{array}$ & $\begin{array}{l}-0.23 \\
(0.17)\end{array}$ & $\begin{array}{l}-0.24 \\
(0.18)\end{array}$ \\
\hline Current spending index $t-1$ & & & $\begin{array}{l}0.29 \\
(0.20)\end{array}$ & $\begin{array}{l}0.28 \\
(0.20)\end{array}$ & $\begin{array}{l}0.28 \\
(0.20)\end{array}$ & $\begin{array}{l}0.35^{*} \\
(0.21)\end{array}$ & $\begin{array}{l}0.37 * \\
(0.22)\end{array}$ \\
\hline Autonomy index $t-1$ & & & & $\begin{array}{l}-0.02 \\
(0.08)\end{array}$ & $\begin{array}{l}-0.02 \\
(0.08)\end{array}$ & $\begin{array}{l}0.00 \\
(0.08)\end{array}$ & $\begin{array}{l}0.03 \\
(0.09)\end{array}$ \\
\hline Residual index $t-1$ & & & & & $\begin{array}{l}-0.00 \\
(0.01)\end{array}$ & $\begin{array}{l}-0.00 \\
(0.01)\end{array}$ & $\begin{array}{l}-0.01 \\
(0.01)\end{array}$ \\
\hline Personnel index $t-1$ & & & & & & $\begin{array}{l}0.25 \\
(0.23)\end{array}$ & $\begin{array}{l}0.17 \\
(0.27)\end{array}$ \\
\hline Macrovariables & No & No & No & No & No & No & Yes \\
\hline Year dummies & Yes & Yes & Yes & Yes & Yes & Yes & Yes \\
\hline Number of observations & 320 & 320 & 320 & 320 & 320 & 320 & 320 \\
\hline Number of groups & 32 & 32 & 32 & 32 & 32 & 32 & 32 \\
\hline Pseudo- $R$-squared & 0.22 & 0.23 & 0.23 & 0.24 & 0.24 & 0.24 & 0.24 \\
\hline Log-likelihood value & -87.44 & -86.64 & -85.96 & -85.20 & -85.12 & -84.98 & -83.98 \\
\hline Prob $>$ Chi-square & 0.05 & 0.07 & 0.08 & 0.11 & 0.15 & 0.16 & 0.35 \\
\hline
\end{tabular}

Panel logit model. The explanatory variables are lagged $(t-1)$ to avoid simultaneity issues. Marginal effects are calculated at the sample means of the explanatory variables. Pseudo- $R$-squared is calculated as suggested by McFadden (1974). Results are confirmed when macrovariables are included in regressions specification (1)-(6)

$* * *(* *, *)$ Statistical significance at the $1(5,10)$ percent level.

subsection. $T$ are time dummies, and $\epsilon$ is the error term. In order to avoid simultaneity issues, budget indicators are lagged at $t-1$.

\section{Results and robustness checks}

Table 3 shows the result of the logit model as described in Sect. 2.2. Firstly, there is a bivariate regression (column 1) and then each independent variable is added one by one among the regressors. In all specifications, the debt indicator (the annual loan repayment over total spending ${ }^{11}$ ) is significant in affecting the default probability: Ceteris paribus, a 10 percentage points increase in the principal index at the sample means increases the default probability by a percentage by $2.6 \%$, when both macroeconomic

\footnotetext{
11 Since there are multiple budget indicators that can signal the presence of debt sustainability, we ran the model alternatively using the following three indicators of debt burden: annual loan repayment, interest paid on debt and new principal. Results do not change significantly.
} 
Table 4 Probability of default with fixed effects
Panel logit model. The explanatory variables are lagged $(t-1)$ to avoid simultaneity issues. Pseudo- $R$-squared is calculated as suggested by McFadden (1974) *** (**,*) Statistical significance at the $1(5,10)$ percent level

\begin{tabular}{|c|c|c|c|}
\hline & Default & Default & Default \\
\hline & (1) & (2) & (3) \\
\hline \multirow[t]{2}{*}{ Principal index $t-1$} & $10.52 * * *$ & $10.35 * * *$ & $9.56 * * *$ \\
\hline & $(2.49)$ & $(2.51)$ & $(2.63)$ \\
\hline \multirow[t]{2}{*}{ Current revenues index $t-1$} & -3.83 & -4.54 & -4.97 \\
\hline & $(3.12)$ & $(3.36)$ & $(3.63)$ \\
\hline \multirow[t]{2}{*}{ Current spending index $t-1$} & $6.55^{*}$ & $7.11^{*}$ & $7.80^{*}$ \\
\hline & $(3.87)$ & $(4.16)$ & $(4.47)$ \\
\hline \multirow[t]{2}{*}{ Autonomy index $t-1$} & 0.03 & -0.94 & 0.53 \\
\hline & $(1.67)$ & $(1.84)$ & $(2.40)$ \\
\hline \multirow[t]{2}{*}{ Residual index $_{t-1}$} & -0.20 & -0.21 & -0.15 \\
\hline & $(0.19)$ & $(0.19)$ & $(0.19)$ \\
\hline \multirow{2}{*}{ Personnel index $t-1$} & 5.56 & 6.39 & 6.38 \\
\hline & $(6.48)$ & $(6.64)$ & $(6.77)$ \\
\hline Fixed effects & Yes & Yes & Yes \\
\hline Macrovariables & No & Yes & Yes \\
\hline Year dummies & No & No & Yes \\
\hline Number of observations & 348 & 348 & 348 \\
\hline Number of groups & 29 & 29 & 29 \\
\hline Pseudo- $R$-squared & 0.19 & 0.21 & 0.31 \\
\hline Log-likelihood value & -58.66 & -56.71 & -49.56 \\
\hline Prob $>$ Chi-square & 0.00 & 0.00 & 0.00 \\
\hline
\end{tabular}

control variables and year dummies are included (column 7). ${ }^{12}$ Our results confirm on a local level what economic literature (Davig et al. 2011; Bi 2012 and Bi et al. 2014) has recently been pointing out on a national or international level: An economy hits its fiscal limit when the debt level rises to the point where current spending is too constrained and the government loses the ability to finance it by increasing taxes. In the analysis this issue is even more relevant, as - unlike what happens at national level — current revenue must cover not only the interest payments but also the principal component (i.e., rollover of debt is not allowed). Other than the debt indicator, there is weak evidence (column 7), considering a 10 percentage point increase, of statistical significance for the current spending index (with a positive average marginal effect of $3.7 \%$ ). It is relevant to note that the personnel index is never statistically significant; thus, there is not any evidence that this indicator has increased default probability in the sample.

We also implemented some alternative specifications of the model so as to test the robustness of the results.

Table 4 shows a panel logit model with fixed effects. The inclusion of fixed effects permits to control for time-invariant parameters, but do not allow to calculate the

\footnotetext{
12 For a detailed explanation on how to interpret the results, see Williams (2012).
} 
Table 5 Probability of default with fixed effects and lags

\begin{tabular}{|c|c|c|c|}
\hline & Default & Default & Default \\
\hline & (1) & (2) & (3) \\
\hline \multirow[t]{2}{*}{ Principal index $t-1$} & $8.95 * * *$ & $8.77 * * *$ & $7.83 * * *$ \\
\hline & $(2.69)$ & $(2.82)$ & $(2.86)$ \\
\hline \multirow[t]{2}{*}{ Principal index $t-2$} & $5.53 * *$ & $5.63 *$ & $5.97 *$ \\
\hline & $(2.70)$ & $(2.88)$ & $(3.43)$ \\
\hline \multirow[t]{2}{*}{ Current revenues index $t-1$} & -4.87 & -4.95 & -5.60 \\
\hline & $(3.39)$ & $(3.54)$ & $(3.79)$ \\
\hline \multirow[t]{2}{*}{ Current revenues index $t-2$} & -3.11 & -3.62 & -4.20 \\
\hline & $(3.56)$ & $(3.80)$ & $(4.25)$ \\
\hline \multirow[t]{2}{*}{ Current spending index $t-1$} & $8.83 * *$ & $8.84 * *$ & $9.47 * *$ \\
\hline & $(4.22)$ & $(4.37)$ & $(4.68)$ \\
\hline \multirow[t]{2}{*}{ Current spending index $t-2$} & 1.59 & 1.93 & 2.29 \\
\hline & $(4.48)$ & $(4.76)$ & $(5.29)$ \\
\hline \multirow[t]{2}{*}{ Autonomy index $t-1$} & -0.34 & -1.97 & 0.04 \\
\hline & $(1.93)$ & $(2.17)$ & $(2.77)$ \\
\hline \multirow[t]{2}{*}{ Autonomy index $t-2$} & -1.04 & 0.41 & 0.78 \\
\hline & $(3.65)$ & $(3.73)$ & $(3.88)$ \\
\hline \multirow[t]{2}{*}{ Residual index $t_{t-1}$} & -0.20 & -0.24 & -0.21 \\
\hline & $(0.19)$ & $(0.19)$ & $(0.21)$ \\
\hline \multirow[t]{2}{*}{ Residual index $t-2$} & -0.00 & 0.02 & 0.02 \\
\hline & $(0.17)$ & $(0.17)$ & $(0.16)$ \\
\hline \multirow[t]{2}{*}{ Personnel index $t-1$} & 4.78 & 5.81 & 7.35 \\
\hline & $(7.70)$ & $(7.87)$ & $(8.25)$ \\
\hline \multirow[t]{2}{*}{ Personnel index $t-2$} & 4.86 & 4.86 & 2.73 \\
\hline & $(7.52)$ & $(7.60)$ & $(8.12)$ \\
\hline Fixed effects & Yes & Yes & Yes \\
\hline Macrovariables & No & Yes & Yes \\
\hline Year dummies & No & No & Yes \\
\hline Number of observations & 319 & 319 & 319 \\
\hline Number of groups & 29 & 29 & 29 \\
\hline Pseudo- $R$-squared & 0.24 & 0.27 & 0.34 \\
\hline Log-likelihood value & -52.87 & -51.10 & -45.93 \\
\hline Prob $>$ Chi-square & 0.00 & 0.00 & 0.01 \\
\hline
\end{tabular}

Panel logit model. The explanatory variables are lagged ( $t-$ $1, t-2)$ to avoid simultaneity issues. Further lags are added as a robustness check. Pseudo$R$-squared is calculated as suggested by McFadden (1974)

*** (**, *) Statistical

significance at the $1(5,10)$

percent level

marginal effects and therefore it is lost the economic interpretability of the coefficients. Nevertheless, it is still possible to interpret their sign and statistical significance. More specifically, it is confirmed that both an increase in the principal index and current spending index foster the probability of default (see specifications 1,2 and 3).

Adding a further $\operatorname{lag}^{13}$ in budget indexes (see Table 5) confirms that the principal and the spending revenue indexes affect the default event. Interestingly, the principal

\footnotetext{
13 Results are confirmed also adding budget indexes with three lags.
} 
Table 6 Probability of default, controlling for high-debt levels

\begin{tabular}{|c|c|c|c|c|c|c|}
\hline & Default & Default & Default & Default & Default & Default \\
\hline & (1) & (2) & (3) & (4) & (5) & (6) \\
\hline Principal index $t-1$ & $\begin{array}{l}9.56 * * * \\
(2.63)\end{array}$ & & & $\begin{array}{l}7.52 * * \\
(3.24)\end{array}$ & & \\
\hline Principal-current spending index $t-1$ & & $\begin{array}{l}2.34 * * \\
(0.91)\end{array}$ & & & $\begin{array}{l}0.63 \\
(1.15)\end{array}$ & \\
\hline Principal-capital spending index $t-1$ & & & $\begin{array}{l}0.04 * \\
(0.02)\end{array}$ & & & $\begin{array}{l}0.02 \\
(0.02)\end{array}$ \\
\hline Current revenues index $t-1$ & $\begin{array}{l}-4.97 \\
(3.63)\end{array}$ & $\begin{array}{l}-4.23 \\
(3.33)\end{array}$ & $\begin{array}{l}-2.11 \\
(3.19)\end{array}$ & $\begin{array}{l}-4.99 \\
(3.68)\end{array}$ & $\begin{array}{l}-4.93 \\
(3.55)\end{array}$ & $\begin{array}{l}-4.93 \\
(3.55)\end{array}$ \\
\hline Current spending index $t-1$ & $\begin{array}{l}7.80 * \\
(4.47)\end{array}$ & $\begin{array}{l}7.45^{*} \\
(4.16)\end{array}$ & $\begin{array}{l}2.57 \\
(4.05)\end{array}$ & $\begin{array}{l}8.33 * \\
(4.55)\end{array}$ & $\begin{array}{l}8.74 * * \\
(4.39)\end{array}$ & $\begin{array}{l}8.74 * * \\
(4.39)\end{array}$ \\
\hline Autonomy index $t-1$ & $\begin{array}{l}0.53 \\
(2.40)\end{array}$ & $\begin{array}{l}0.43 \\
(2.35)\end{array}$ & $\begin{array}{l}-0.50 \\
(2.63)\end{array}$ & $\begin{array}{l}0.87 \\
(2.42)\end{array}$ & $\begin{array}{l}1.53 \\
(2.45)\end{array}$ & $\begin{array}{l}1.53 \\
(2.45)\end{array}$ \\
\hline Residual index $t-1$ & $\begin{array}{l}-0.15 \\
(0.19)\end{array}$ & $\begin{array}{l}-0.10 \\
(0.18)\end{array}$ & $\begin{array}{l}-0.13 \\
(0.21)\end{array}$ & $\begin{array}{l}-0.12 \\
(0.19)\end{array}$ & $\begin{array}{l}-0.06 \\
(0.18)\end{array}$ & $\begin{array}{l}-0.06 \\
(0.18)\end{array}$ \\
\hline Personnel index $t-1$ & $\begin{array}{l}6.38 \\
(6.77)\end{array}$ & $\begin{array}{l}5.14 \\
(6.03)\end{array}$ & $\begin{array}{l}5.19 \\
(6.30)\end{array}$ & $\begin{array}{l}6.18 \\
(6.86)\end{array}$ & $\begin{array}{l}4.49 \\
(6.47)\end{array}$ & $\begin{array}{l}4.49 \\
(6.47)\end{array}$ \\
\hline Fixed effects & Yes & Yes & Yes & Yes & Yes & Yes \\
\hline Macrovariables & Yes & Yes & Yes & Yes & Yes & Yes \\
\hline Year dummies & Yes & Yes & Yes & Yes & Yes & Yes \\
\hline High-debt dummy & No & No & No & Yes & Yes & Yes \\
\hline Number of observations & 348 & 348 & 335 & 348 & 348 & 335 \\
\hline Number of groups & 29 & 29 & 28 & 29 & 29 & 28 \\
\hline Pseudo- $R$-squared & 0.31 & 0.24 & 0.25 & 0.32 & 0.28 & 0.31 \\
\hline Log-likelihood value & -49.56 & -54.96 & -51.95 & -49.03 & -51.89 & -49.73 \\
\hline Prob $>$ Chi-square & 0.00 & 0.03 & 0.03 & 0.00 & 0.01 & 0.01 \\
\hline
\end{tabular}

Panel logit model. The explanatory variables are lagged $(t-1)$ to avoid simultaneity issues. In columns 4-6 is included a high-debt dummy, to control for a high-debt condition, which takes value 1 when the per-capita debt is higher than the average level in our sample. Pseudo- $R$-squared is calculated as suggested by McFadden (1974)

$* * *(* *, *)$ Statistical significance at the $1(5,10)$ percent level

index is also significant, even if with a lower intensity, 2 years before the default event. Robustness checks do not alter the nonsignificance of personnel index.

Considering that the analysis shows that, if everything else being equal, an increase in the ratio of loan repayment over total spending raises default probability, we explore whether the local government is less willing to pay their debt when loan repayment squeezes out other spending categories or the issue is more related to its inability to service the debt. Therefore, we study the different effect of the "principal-current" spending index and the "principal-capital" spending index (as defined in Sect. 2.1 and detailed in Table 1), controlling for a high-debt condition using a dummy variable 
which takes value 1 when the per-capita debt is higher than the average level in our sample. Table 6 shows that results are not driven by a squeeze in subcomponent of spending categories (i.e., current and capital) due to the principal (specifications 2 and 3). In addition, when the control for high-debt levels is added, principal-current and principal-capital indexes are not significant anymore (specifications 5 and 6). This result suggests that it is the local governments inability to service its debt that increases default probability.

\section{Conclusions}

This paper empirically studies the main determinants of Italian municipalities' default using a panel dataset over the period 2000-2012. Creating a binary local default indicator, this study implements binary regression models to evaluate which budget components have a major impact on local default. The main indicators that have been used are the following ones: loan repayment, current budget equilibrium (investigated through three indexes: current revenue, current spending and their ratio), amount of residuals and personnel costs. Results show that the main variable positively affecting the default probability is the share of loan repayment over total spending: A ten percent increase in this index increases the probability of fiscal distress by $2.6 \%$ on average. Weaker evidence on the current expenditure index is also found. In other words, the results do not point toward the loss of control of current spending/revenue to be the main default's determinant, nor the share of personnel cost over total spending. Rather, municipalities seem to be on the default path when they are incapable to fully internalize the effects of issuing new debt today on the current equilibrium of tomorrow. This evidence supports the view that to maintaining local debt under control should be a central goal for both local and national policy makers, in order to avoid local default episodes that generate economic and social instability. At the same time, the effectiveness of budget constraints other than the usual balanced budget, such as the limitations in particular subcategories of spending, in providing insurance against future default may be questioned.

Open Access This article is distributed under the terms of the Creative Commons Attribution 4.0 International License (http://creativecommons.org/licenses/by/4.0/), which permits unrestricted use, distribution, and reproduction in any medium, provided you give appropriate credit to the original author(s) and the source, provide a link to the Creative Commons license, and indicate if changes were made.

\section{References}

Afonso A, Fernandes S (2006) Measuring local government spending efficiency: evidence for the Lisbon region. Reg Stud 40(1):39-53

Akin JS (1973) Fiscal capacity and the estimation method of the advisory commission on intergovernmental relations. Natl Tax J 26(2):275-294

Akin JS (1974) An improved method for estimating local fiscal capacity. Rev Reg Stud 4(2):33-48

Amemiya T (1981) Qualitative response models: a survey. J Econ Lit 19:1483-1536

Bi H (2012) Sovereign default risk premia, fiscal limits, and fiscal policy. Eur Econ Rev 56(3):389-410 
Bi H, Shen W, Yang S (2014) Fiscal limits, external debt, and fiscal policy in developing countries. IMF working paper, 1449

Buettner T, Wildasin DE (2006) The dynamics of municipal fiscal adjustment. J Public Econ 90(6):11151132

Capeci J (1994) Local fiscal policies, default risk, and municipal borrowing costs. J Public Econ 53(1):73-89

Davig T, Leeper EM, Walker TB (2011) Inflation and the fiscal limit. Eur Econ Rev 55(1):31-47

Dexia (2006) Subnational public finance in the European Union. Local Dexia Credit, Economic Outlook

Di Liddo G, Longobardi E, Porcelli F (2016) Measuring horizontal fiscal imbalances: the case of Italian municipalities. Local Gov Stud 42(3):385-419

Epple D, Spatt C (1986) State restrictions on local debt: their role in preventing default. J Public Econ 29(2):199-221

Grossman PJ, Mavros P, Wassmer RW (1999) Public sector technical inefficiency in large US cities. J Urban Econ 46(2):278-299

Hausmann R (1998) Fiscal institutions for decentralising democracies: which way to go? in democracy. Decentralisation and Deficits in Latin America, Development Centre of the Organization for Economic Co-operation and Development

Jorra M (2012) The effect of IMF lending on the probability of sovereign debt crises. J Int Money Financ 31(4):709-725

King G, Zeng L (2001) Logistic regression in rare events data. Political Anal 9(2):137-163

Lobo FC, Ramos P, Lourenco O (2011) Causes of financial distress of Portuguese municipalities: empirical evidence. Int J Monet Econ Financ 4(4):390-409

Manasse P, Roubini N (2009) Rules of thumb for sovereign debt crises. J Int Econ 78(2):192-205

Martinez-Vazquez J, Boex LFG (1997a) An analysis of alternative measures of fiscal capacity for the regions of the Russian Federation. International studies program working paper, 97-4. Andrew Young School of Policy Studies, Georgia State University

Martinez-Vazquez J, Boex LFG (1997b) Fiscal capacity: an overview of concept and measurement issues and their applicability in the Russian Federation. International studies program working paper, 97-3. Andrew Young School of Policy Studies, Georgia State University

McFadden D (1974) Conditional logit analysis of qualitative choice behavior. In: Zarembka P (ed) Frontiers in econometrics. Academic Press, New York, pp 105-142

Nicolini JP, Posadas J, Sanguinetti J, Sanguinetti P, Tommasi M (2002) Decentralization, fiscal discipline in sub-national governments and the bailout problem: the case of Argentina. IDB working paper, 467

Richard A, Musgrave PB (1989) Public finance in theory and practice. McGraw Hill, New York

Schaltegger CA, Weder M (2015) Fiscal adjustments and the probability of sovereign default. Kyklos 68(1):81-110

Skidmore M (1999) Tax and expenditure limitations and the fiscal relationships between state and local governments. Public Choice 99(1-2):77-102

Skidmore M, Scorsone E (2011) Causes and consequences of fiscal stress in Michigan cities. Reg Sci Urban Econ 41(4):360-371

Van Rijckeghem C, Weder B (2009) Political institutions and debt crises. Public Choice 138(3-4):387-408

Von Hagen J, Eichengreen B (1996) Federalism, fiscal restraints, and European monetary union. Am Econ Rev 86:134-138

Von Hagen J, Bordignon M, Dahlberg M, Grewal BS, Peterson P, Seitz H (2000) Subnational government bailouts in OECD countries: four case studies. IDB working paper, 399

Wildasin DE (1997) Externalities and bailouts: hard and soft budget constraints in intergovernmental fiscal relations, vol 1843. World Bank Publications, Washington, DC

Williams R (2012) Using the margins command to estimate and interpret adjusted predictions and marginal effects. Stata J 12(2):308

Wooldridge JM (2010) Econometric analysis of cross section and panel data. MIT press, Cambridge

Worthington A, Dollery B (2000) An empirical survey of frontier efficiency measurement techniques in local government. Local Gov Stud 26(2):23-52

Yilmaz YS, Hoo S, Nagowski M, Tannewald R (2006) Measuring fiscal disparities across the US States: a representative revenue system, representative expenditure system approach, fiscal year 2002. Federal Reserve Bank of Boston, occasional papers, 74. The Urban Institute, Washington DC 